\title{
Pengaruh Perilaku Ibu Selama Kehamilan terhadap Status Kehamilan yang Tidak Diinginkan di Indonesia
}

\section{The Effect of Maternal Behavior During Pregnancy towards Unwanted Pregnancy Status in Indonesia}

\author{
Essi Guspaneza*, Evi Martha \\ Departemen Promosi Kesehatan dan Ilmu Perilaku, Fakultas Kesehatan Masyarakat, \\ Universitas Indonesia \\ (*essiguspaneza1908@gmail.com)
}

\begin{abstract}
ABSTRAK
Status kehamilan yang tidak dinginkan terjadi karena ibu tidak siap untuk hamil dan akan berdampak pada perilaku ibu selama kehamilan yaitu ibu cenderung tidak melakukan kunjungan pelayanan antenatal atau kunjungan pemeriksaan kehamilan. Penelitian ini bertujuan mengetahui pengaruh perilaku ibu selama kehamilan terhadap status kehamilan yang tidak diinginkan. Jenis Penelitian ini adalah kuantitatif dengan menggunakan desain cross-sectional studi. Populasinya adalah semua wanita hamil dari data Survei Demografi dan Kesehatan Indonesia (SDKI) tahun 2017 di Indonesia berjumlah 1990 wanita, dianalisis secara univariat, bivariat dan multivariat. Hasil penelitian menunjukan wanita yang mengalami kehamilan yang tidak diinginkan sebesar $12,8 \%$ dan menunjukkan ada hubungan antara perilaku ibu selama kehamilan $(p=0,0001 ; \mathrm{OR}=39,640)$ dengan kehamilan yang tidak diinginkan, setelah dikontrol oleh variabel umur saat hamil dan paritas. Probabilitas ibu yang tidak melakukan kunjungan Antenal Care (ANC), paritas $>3$ serta umur saat hamil $<20$ atau $>35$ tahun yang mengalami status kehamilan yang tidak diinginkan sebesar $55 \%$. Kesimpulan dari penelitian ini adalah adanya pengaruh perilaku ibu selama kehamilan (kunjungan ANC) terhadap status kehamilan yang tidak diinginkan. Kata kunci: Kunjungan ANC, kehamilan tidak diinginkan
\end{abstract}

\section{ABSTRACT}

Unwanted pregnancy status occurs because the mother have not ready to get pregnant and will the impact on maternal behavior during pregnancy made mother tend to less doing the antenatal care visits, or prenatal care visits. This study aims to know the effect of maternal behavior during pregnancy towards unwanted pregnancy status. This study is a quantitative with using cross-sectional study design. The population is all pregnant women from 2017 IDHS survey in Indonesia of 1990 women, analyzed with univariate, bivariate and multivariate. The results of the research showed women who having unwanted pregnancy of $12.8 \%$ and there are relationship between maternal behavior during pregnancy $(p=0.0001 ; O R=39,640)$ with unwanted pregnancy, after controlled age at pregnancy and parity. The probability of mothers who not doing ANC visit, parity $>3$ and age at pregnancy $<20$ or $>35$ years having unwanted pregnancy status by $55 \%$. Conclusion of this study is that there are effect maternal behavior during pregnancy (ANC visits) towards unwanted pregnancy status. Keywords: ANC visits, unwanted pregnancy 


\section{PENDAHULUAN}

Jumlah kehamilan yang tidak diinginkan terjadi peningkatan pada saat ini. Secara global terdapat 208 juta kehamilan di dunia. Sebesar 185 juta kehamilan diantaranya terjadi di negara berkembang, dan sebesar 86 juta (41\%) dari kehamilan di dunia merupakan kehamilan tidak diinginkan. ${ }^{1}$ Kehamilan tidak diinginkan di negara berkembang (29\%) lebih tinggi dibandingkan di negara maju $(20 \%){ }^{2}$

Prevalensi kejadian kehamilan tidak diinginkan didunia, tertinggi terjadi di Asia (54\%). ${ }^{2}$ Berdasarkan Data Survei Demografi dan Kesehatan Indonesia (SDKI) menunjukkan bahwa prevalensi kejadian kehamilan tidak diinginkan di Indonesia pada tahun 2017 yaitu sebesar 14\%. Angka ini lebih besar jika dibandingkan dengan data Riskesdas 2013 yang hanya sebesar 5,8\%. ${ }^{3}$ Artinya dari data tersebut menunjukan adanya peningkatan prevalensi kehamilan yang tidak diinginkan sebesar $8,2 \%$ pada tahun 2017 . Kehamilan yang tidak diinginkan dapat menyebabkan 700,000 kematian ibu setiap tahunnya. ${ }^{4}$ Ajzen dan Fishbein dalam Notoatmodjo menyatakan bahwa keinginan seseorang untuk berperilaku merupakan determinan utama dari perilaku individu tersebut. Bagi ibu yang tidak menginginkan kehamilannya akan merasa tidak siap hamil sehingga cenderung untuk tidak mengurus kehamilannya dengan baik, yang dapat berisiko pada kesehatan bayinya dan perawatan bayinya setelah melahirkan. ${ }^{5}$

Studi menunjukkan bahwa wanita dengan kehamilan yang tidak diinginkan cenderung lebih sedikit melakukan kunjungan pelayanan antenatal atau kunjungan pemeriksaan kehamilan. Penelitian yang dilakukan D'angelo, dkk menunjukkan bahwa wanita dengan kehamilan yang tidak diinginkan memiliki peluang 2,1 kali untuk tidak memeriksakan kehamilannya. ${ }^{6}$

Beberapa penelitian yang menunjukkan faktor yang berhubungan dengan kehamilan yang tidak diinginkan, seperti usia saat hamil, pendidikan, status pekerjaan, status hidup bersama, status perkawinan, status sosial ekonomi, paritas, jumlah anak, komplikasi kehamilan, dan penggunaan kontrasepsi. Hal yang sama ditemukan dalam penelitian oleh Abdallah yaitu menemukan proporsi wanita dengan pendidikan rendah $(13,4 \%)$ lebih besar untuk mengalami kehamilan tidak diingin- kan daripada kehamilan yang diinginkan $(4,1 \%){ }^{7}$

Penelitian Gipson JD menunjukkan bahwa wanita yang berusia di bawah 20 tahun mempunyai kemungkinan risiko 2,7 kali mengalami kehamilan tidak diinginkan dan 2,3 kali pada wanita usia di atas 35 tahun. ${ }^{8}$ Hal serupa didapatkan pada penelitian yang dilakukan oleh Ramesh Adikari juga mendapatkan bahwa paritas berhubungan dengan kejadian kehamilan tidak diinginkan. ${ }^{9}$ Selain itu, Palamuleni (2014) juga menyebutkan bahwa paritas yang tinggi berhubungan dengan kehamilan tidak diinginkan. ${ }^{10}$

Berdasarkan permasalahan diatas Pemerintah Indonesia memberi perhatian terhadap status kesehatan ibu dan anak, sehingga informasi yang berkaitan terhadap keinginan untuk hamil pada ibu bermanfaat untuk berbagai tujuan, seperti memperkirakan jumlah kehamilan tidak diinginkan dan selanjutnya untuk memperkirakan dampak status kehamilan terhadap perilaku ibu selama kehamilan, kesehatan dan perkembangan anak yang lahir dari kehamilan yang tidak diinginkan. Selama ini sudah banyak penelitian dan analisis tentang kehamilan yang tidak diinginkan, seperti analisis determinan kehamilan yang tidak diinginkan, pengaruh KTD terhadap berat badan bayi lahir rendah dan analisis lainnya terkait KTD. Jadi peneliti tertarik melakukan penelitian yang bertujuan untuk melihat pengaruh perilaku ibu selama kehamilan terhadap status kehamilan yang tidak diinginkan di Indonesia Tahun 2017.

\section{BAHAN DAN METODE}

Penelitian ini adalah kuantitatif, menggunakan data sekunder dari SDKI (Survei Demografi dan Kesehatan Indonesia) tahun 2017, dengan desain cross-sectional study. Cross sectional yaitu variabel independen (faktor risiko) dan variabel dependen (efek) dinilai secara bersamaan pada satu waktu. ${ }^{11}$ Variabel dependen dalam penelitian ini adalah kehamilan yang tidak diinginkan, sedangkan variabel independen yaitu perilaku ibu selama hamil (kunjungan ANC), dan variabel covariat-nya adalah umur saat hamil, paritas, tingkat pendidikan, dan status pekerjaan. Populasi dalam penelitian ini adalah semua wanita hamil berusia 15-49 tahun di Indonesia jumlahya sebanyak 2003 dengan 13 data missing, sehingga data lengkap tanpa missing jumlahnya adalah 1990 responden 
di Indonesia dan tercatat di dalam SDKI 2017. ${ }^{4}$

Analisis univariat digunakan untuk mengetahui distribusi frekuensi masing-masing variabel. Analisis bivariat digunakan untuk menganalisis hubungan masing-masing variabel. Variabel yang akan dianalisis dalam penelitian ini adalah variabel independen dan variabel covariat. Analisis bivariat menggunakan uji chi square untuk menemukan kandidat yang akan masuk dalam analisis multivariat. Analisis multivariat menggunakan uji regresi logistik untuk melihat interaksi antar variabel. Berdasarkan teori, ada dua model untuk analisis multivariat, yaitu "model prediksi dan model faktor risiko." Penelitian ini, analisis multivariat menggunakan model faktor risiko yaitu tujuannya untuk mengetahui pengaruh perilaku ibu selama kehamilan terhadap status kehamilan yang tidak diinginkan setelah dikontrol oleh variabel covariat.

\section{HASIL}

Hasil analisis distribusi frekuensi, ditemukan sebagian besar wanita menginginkan kehamilanya yaitu sebesar $87,2 \%$, lebih dari setengah usia wanita hamil di Indonesia berusia 20-35 tahun yaitu sebesar $78,4 \%$. Hampir seluruh wanita di Indonesia memiliki paritas 0-3 anak yaitu sebesar 94,7\%. Lebih dari setengah Wanita di Indonesia memiliki tingkat pendidikan tinggi yaitu sebesar $79 \%$. Serta lebih dari setengah wanita di Indonesia tidak bekerja yaitu sebesar 59,1\%(Tabel 1).

Tabel 2 menunjukan bahwa ada hubunganantaraperilaku selamakehamilan, umursaathamil, dan paritas dengan kehamilan tidak diinginkan, dengan nilai analisis yang diperoleh ( $p=0,0001)$. Tingkat pendidikan dan status kerja dengan kehamilan yang tidak diinginkan dengan masing-masing nilai $p$ adalah 0,934 dan 0,327 . Nilai Odds Ratio (OR) untuk variabel umur saat hamil yang diperoleh adalah 2,146 (95\% CI:1,6162,851 ), kelompok wanita hamil yang berusia $<20$ atau $>35$ tahun memiliki risiko 2,1 kali mengalami kehamilan yang tidak diinginkan dibandingkan dengan wanita hamil pada kelompok usia 20-35 tahun, nilai OR dari variabel paritas yang diperoleh adalah 3,433 (95\% CI:2,222-5,305) yang berarti wanita yang memiliki paritas $>3$ anak akan 3,4 kali berisiko mengalami kehamilan yang tidak diinginkan dibandingkan dengan paritas 0-3 anak.
Tabel 1. Karakteristik Responden

\begin{tabular}{|c|c|c|}
\hline Variabel & $\mathbf{n}$ & $\%$ \\
\hline \multicolumn{3}{|l|}{ Status Kehamilan } \\
\hline Kehamilan diinginkan & 1735 & 87,2 \\
\hline Kehamilan Tidak diinginkan & 255 & 12,8 \\
\hline \multicolumn{3}{|l|}{$\begin{array}{l}\text { Perilaku Ibu Selama Kehamilan } \\
\text { (Kunjungan ANC) }\end{array}$} \\
\hline Melakukan Kunjungan ANC & 1653 & 83,1 \\
\hline Tidak Melakukan Kunjungan ANC & 337 & 16,9 \\
\hline \multicolumn{3}{|l|}{ Umur Saat Hamil } \\
\hline 20-35 tahun & 1560 & 78,4 \\
\hline$<20$ atau $>35$ tahun & 430 & 21,6 \\
\hline \multicolumn{3}{|l|}{ Paritas } \\
\hline 0-3 anak & 1885 & 94,7 \\
\hline$>3$ anak & 105 & 21,0 \\
\hline \multicolumn{3}{|l|}{ Tingkat Pendidikan } \\
\hline Pendidikan Tinggi & 1572 & 79 \\
\hline Pendidikan Rendah & 418 & 21 \\
\hline \multicolumn{3}{|l|}{ Status Pekerjaan } \\
\hline Tidak Bekerja & 1177 & 59,1 \\
\hline Bekerja & 813 & 40,9 \\
\hline
\end{tabular}

Berdasarkan Tabel 3 dari ouput model lengkap dilakukan uji interaksi, variabel dikatakan berinteraksi bila nila $p<0,05$. Seleksinya dengan mengeluarkan secara bertahap variabel interaksi yang tidak signifikan $(p>0,05)$ pengeluaran dilakukan secara bertahap dari variabel interaksi yang $p$ terbesar. Variabel interaksi "perawatan kehamilan by paritas" mempunyai nilai $p$ terbesar $(p=0,998)$ sehingga variabel tersebut dikeluarkan dari model terlebih dahulu kemudian dilakukan analisis kembali. Selanjutnya dilanjutkan dengan mengeluarkan variabel interaksi lainnya yang nilai $p>0,05$ yaitu variabel perawatan kehamilan (ANC) by umur saat hamil, didapatkan kesimpulan bahwa tidak ada variabel yang mengalami interaksi karena $p$ lebih besar dari 0,05 .

Persamaan model regresi logistik adalah logit status kehamilan yang tidak diingin$k a n=-3,414+3,680$ (Perawatan kehamilan) $+0,613$ (Umur saat hamil) + -0,675 (Paritas), dan berdasarkan hasil dari analisis multivariat regresi logistik didapatkan ada hubungan yang bermakna secara statistik antara perilaku perawatan kehamilan (ANC) dengan status kehamilan yang tidak diinginkan $(p=0,0001)$ dengan nilai $\mathrm{OR}=39,640$ artinya ibu yang tidak melakukan perawatan kehamilan (ANC) mempunyai status kehamilan yang tidak 
Tabel 2. Analisis Bivariat dari Perilaku Ibu Selama Kehamilan terhadap Status Kehamilan yang Tidak Diinginkan di Indonesia

\begin{tabular}{|c|c|c|c|c|c|c|}
\hline \multirow[t]{2}{*}{ Variabel } & \multicolumn{2}{|c|}{$\begin{array}{l}\text { Kehamilan } \\
\text { diinginkan }\end{array}$} & \multicolumn{2}{|c|}{$\begin{array}{c}\text { Kehamilan Tidak } \\
\text { Diinginkan }\end{array}$} & \multirow[t]{2}{*}{ p value } & \multirow[t]{2}{*}{ OR $(95 \%$ CI $)$} \\
\hline & $\mathbf{n}$ & $\%$ & $\mathbf{n}$ & $\%$ & & \\
\hline \multicolumn{7}{|l|}{ Variabel Independen } \\
\hline \multicolumn{7}{|l|}{$\begin{array}{l}\text { Perilaku Ibu Selama Kehamilan } \\
\text { (Kunjungan ANC) }\end{array}$} \\
\hline Melakukan Kunjungan ANC & 1593 & 96,4 & 60 & 3,6 & 0,0001 & 36,46 \\
\hline Tidak Melakukan Kunjungan ANC & 142 & 42,1 & 195 & 57,9 & & $(26,043-51,041)$ \\
\hline \multicolumn{7}{|l|}{ Variabel Covariat } \\
\hline \multicolumn{7}{|l|}{ Umur Saat Hamil } \\
\hline 20-35 tahun & 1393 & 89,3 & 167 & 10,7 & 0,0001 & 2,146 \\
\hline$<20$ atau $>35$ tahun & 342 & 79,5 & 88 & 20,5 & & $(1,616-2,851)$ \\
\hline \multicolumn{7}{|l|}{ Paritas } \\
\hline 0-3 anak & 1663 & 88,2 & 222 & 11,8 & 0,0001 & 3,433 \\
\hline$>3$ anak & 72 & 68,6 & 33 & 31,4 & & $(2,222-5,305)$ \\
\hline \multicolumn{7}{|l|}{ Tingkat Pendidikan } \\
\hline Pendidikan Tinggi & 1371 & 87,2 & 201 & 20,8 & 0,934 & 1,012 \\
\hline Pendidikan Rendah & 364 & 87,1 & 54 & 12,9 & & $(0,733-1,396)$ \\
\hline \multicolumn{7}{|l|}{ Status Pekerjaan } \\
\hline Tidak Bekerja & 1019 & 86,6 & 158 & 13,4 & 0,327 & 0,874 \\
\hline Bekerja & 716 & 88,1 & 97 & 11,9 & & $(0,667-1,145)$ \\
\hline
\end{tabular}

Sumber: Data Sekunder SDKI, 2017

diinginkan sebesar 39 kali lebih tinggi, dibandingkan dengan ibu yang melakukan perawatan kehamilan (ANC) saat hamil setelah dikontrol oleh variabel umur saat hamil dan variabel paritas (Tabel 4). Probabilitas Ibu yang tidak melakukan perawatan kehamilan (ANC) yang mengalami status kehamilan yang tidak diinginkan berdasarkan nilai-nilai nrediktor dihitıng dengan nersamaan:

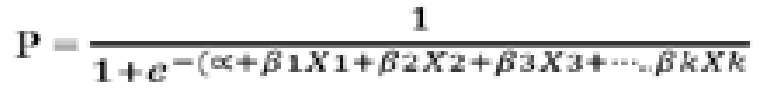

Maka Probabilitas Ibu yang tidak melakukan perawatan kehamilan (ANC), paritas $>3$ serta umur saat hamil $<20$ atau $>35$ tahun :

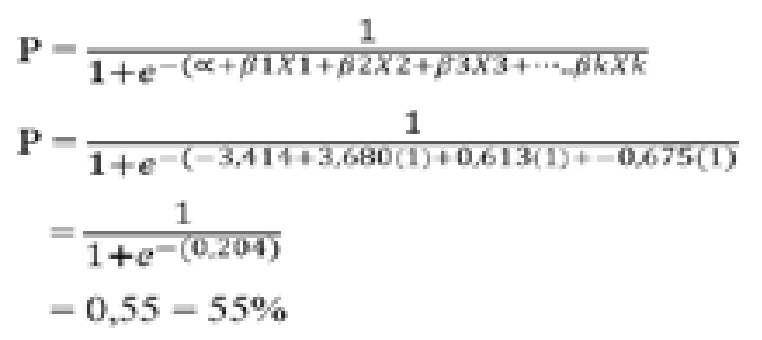

Artinya probabilitas ibu yang tidak melakukan perawatan kehamilan (ANC), paritas $>3$ serta umur saat hamil $<20$ atau $>35$ tahun yang mengalami status kehamilan yang tidak diinginkan sebesar 55\%.

\section{PEMBAHASAN}

Kehamilan yang tidak diinginkan ini adalah kehamilan yang terjadi ketika tidak menginginkan kelahiran anak. ${ }^{12}$ Beberapa faktor yang dapat menyebabkan seseorang mengalami status kehamilan yang tidak diinginkan yaitu salah perilaku perawatan kehamilan usia saat hamil dan paritas sehingga dapat menyebabkan seseorang tersebut cenderung tidak ingin melakukan perawatan selama kelahiran. Hasil penelitian menunjukkan bahwa ibu yang mengalami kehamilan tidak diinginkan mempunyai peluang untuk tidak melakukan perawatan kehamilan (kunjungan antenatal care) 39 kali dibandingkan ibu yang kehamilannya diinginkan. Hasil penelitian ini sejalan dengan penelitian yang dilakukan oleh Anggraini menggunakan data SDKI 2012, ibu yang mengalami kehamilan tidak diinginkan memiliki odds untuk tidak memeriksakan kehamilan secara lengkap 1,4 dibandingkan kehamilan yang diinginkan. ${ }^{13}$

Hasil penelitian ini juga serupa dengan hasil penelitian Hambert yang menunjukkan bahwa wanita yang mengalami kehamilan tidak diinginkan 
Tabel 3. Hasil Analisis Multivariat Uji Interaksi Antar Variabel

\begin{tabular}{lcccc}
\hline \multicolumn{1}{c}{ Variabel } & B & p value & OR & $\mathbf{9 5 \%}$ CI \\
\hline Perawatan Kehamilan (ANC) & 3,630 & 0,0001 & 37,717 & $25,087-56,705$ \\
Umur Saat Hamil & 0,579 & 0,049 & 1,785 & $1,003-3,175$ \\
Paritas & $-18,209$ & 0,998 & 0,000 & 0,000 \\
$\begin{array}{l}\text { Perilaku Ibu Selama Kehamilan (Kunjungan } \\
\text { ANC) by Umur saat hamil }\end{array}$ & 0,071 & 0,856 & 1,073 & $0,501-2,299$ \\
$\begin{array}{l}\text { Perilaku Ibu Selama Kehamilan (Kunjungan } \\
\text { ANC) by Paritas }\end{array}$ & 17,596 & 0,998 & $4 \mathrm{E}+007$ & 0,000 \\
Constant & $-3,388$ & 0,0001 & 0,034 & \\
\hline
\end{tabular}

Sumber: Data Sekunder SDKI, 2017

Tabel 4. Model Akhir Analisis Multivariat dari Pengaruh Perilaku Ibu Selama Kehamilan terhadap Status Kehamilan Tidak Diinginkan di Indonesia

\begin{tabular}{lcccc}
\hline \multicolumn{1}{c}{ Variabel } & B & p value & OR & 95\% CI \\
\hline Perilaku Ibu Selama Kehamilan (Kunjungan & 3,680 & 0,0001 & 39,640 & $27,837-56,446$ \\
ANC) & & & & \\
Umur Saat Hamil & 0,613 & 0,001 & 1,846 & $1,268-2,688$ \\
Paritas & $-0,675$ & 0,014 & 0,509 & $0,297-0,872$ \\
Constant & $-3,414$ & 0,0001 & 0,033 & \\
\hline
\end{tabular}

Sumber: Data Sekunder SDKI, 2017

2,1 kali lebih besar untuk tidak memanfaatkan pelayanan antenatal secara maksimal. ${ }^{14}$ Namun, berbeda dengan hasil penelitian Tosson pada wanita Saudi Arabia, menunjukkan bahwa tidak ada perbedaan jumlah kunjungan pemeriksaan kehamilan pada wanita yang kehamilannya direncanakan dengan wanita yang kehamilannya tidak direncanakan, sehingga dapat disimpulkan tidak terdapat hubungan antara status kehamilan dengan pemeriksaan kehamilan. ${ }^{15}$

Kost dalam penelitiannya mengemukakan, bahwa wanita dengan kehamilan tidak diinginkan memiliki kecenderungan untuk tidak mengenali tanda-tanda awal kehamilan dibandingkan wanita dengan kehamilan yang diinginkan, yang menyebabkan mereka tidak melakukan pemeriksaan sejak awal kehamilan. ${ }^{16}$ Wanita dengan kehamilan tidak diinginkan lebih sedikit untuk termotivasi dalam mencari informasi mengenai kesehatan kehamilan, sehingga dapat mendorong perilaku yang tidak sehat karena mereka tidak peduli pada risiko yang akan terjadi. Penelitian sebelumnya diketahui ibu dengan kehamilan tidak diinginkan lebih sedikit dalam memanfaatkan pelayanan kesehatan, tidak cukup nutrisi, dan stres serta depresi. ${ }^{17}$ Perawatan kehamilan merupakan awal dari continuum of care atau perawatan keberlanjutan dari sejak ibu hamil sampai masa nifas dan dilanjutkan dengan bayi baru lahir sampai usia balita. Saat seorang ibu hamil kontak dengan tenaga kesehatan merupakan peluang bagi tenaga kesehatan memberikan edukasi agar ibu hamil mempunyai pengetahuan yang baik akan pentingnya perawatan kesehatan sejak masa hamil sampai masa nifas serta memberikan pemahaman tentang pentingnya rangkaian perawatan dan akses bayinya. Hasil dari uji confounding bahwa variabel umur saat hamil dan paritas merupakan confounder dari variabel perawatan kehamilan (ANC) sehingga dapat dikatakan bahwa adanya hubungan secara statistik antara perawatan kehamilan (ANC) terhadap status kehamilan yang tidak diinginkan setelah dikontrol oleh umur saat hamil dan paritas.

Umur saat hamil berhubungan signifikan dengan kehamilan yang tidak diinginkan. Hal ini sejalan dengan penelitian yang dilakukan oleh Adhikari bahwa ada hubungan antara usia dengan kehamilan yang tidak diinginkan di Indonesia dengan nilai $p=0,0001 .{ }^{9}$ Selain itu, penelitian ini juga sejalan dengan penelitian yang dilakukan oleh Qurniyawati bahwa ada hubungan antara usia dengan kehamilan yang tidak diinginkan. ${ }^{18} \mathrm{Hal}$ ini sesuai dengan usia reproduksi wanita yang terbaik untuk memiliki anak antara usia 20-35 tahun.

Usia adalah salah satu faktor yang 
menyebabkan kehamilan yang tidak diinginkan, terutama pada wanita yang terlalu muda atau terlalu tua, tidak siap, dan tidak ingin hamil. Secara global, kehamilan pada wanita di bawah 20 tahun akan menyakiti ibu karena ibu secara psikologis tidak siap untuk menjalani kehamilan, sehingga ibu cenderung untuk menolak kehamilannya, karena pada saat itu, ibu belum siap untuk memiliki keturunan meskipun organ reproduksi telah matang pada usia itu. Wanita yang berusia diatas 35 tahun, kesehatan ibu biasanya menurun, sebagai dampaknya wanita yang hamil pada usia itu kemungkinan besar berisiko melahirkan anakanak cacat atau mengalami persalinan yang lama dan perdarahan. Oleh karena itu, pada periode itu, sang ibu menjadi tidak subur (tidak dapat hamil lagi) karena sang ibu sudah terlalu tua. ${ }^{19,20}$ Selain itu, kehamilan pada usia terlalu muda atau terlalu tua dapat menyebabkan ketidaknyamanan bagi wanita, yang berdampak pada aborsi yang disengaja, yang dapat mengancam kesehatan wanita.

Usia 20-35 tahun adalah usia paling aman bagi wanita karena sejak usia 20 tahun, rahim dan bagian tubuh lainnya siap menerima kehamilan dan mereka merasa siap menjadi ibu. Sementara itu, usia lebih dari 35 tahun sudah terlalu tua untuk hamil. Berdasarkan uraian tersebut, terlalu muda atau terlalu tua adalah salah satu penyebab kehamilan berisiko tinggi, yang menghasilkan kehamilan yang tidak diinginkan. Paritas adalah aspek penting yang terkait dengan kehamilan yang tidak diinginkan. Hasil ini sejalan dengan penelitian lain tentang korelasi antara paritas dan kehamilan yang tidak diinginkan, sebab semakin tinggi paritas, semakin tinggi risiko kehamilan yang tidak diinginkan ${ }^{8,21,22}$

Selain itu juga, sejalan dengan penelitian Saptarini, ada korelasi antara paritas dengan kehamilan yang tidak diinginkan dengan nilai $p=0,001$. Namun, penelitian ini berbeda dari penelitian yang dilakukan oleh Ndziessi, yang menyatakan bahwa tidak ada korelasi yang signifikan antara paritas dan kehamilan yang tidak diinginkan dengan nilai $p=0,09$. Menurut Saptarini, semakin banyak anak yang dilahirkan, semakin tinggi kemungkinan memiliki kehamilan yang tidak diinginkan. ${ }^{23}$ Hal ini karena fakta bahwa wanita yang memiliki paritas tinggi mungkin merasa cukup memiliki anak. Aktivitas seksual hanya untuk memenuhi kesenangan daripada memiliki anak.

Wanita yang memiliki banyak anak tetapi masih hamil dengan kehamilan yang tidak diinginkan dapat disebabkan oleh kebutuhan kontrasepsi yang tidak terpenuhi atau karena kegagalan kontrasepsi. Wanita yang telah melahirkan banyak anak juga merasa bahwa jumlah anak telah mencapai angka ideal. Memiliki kehamilan lain, para wanita ini mungkin mengalami peluang lebih besar untuk kehamilan yang tidak diinginkan. Pemerintah telah mempromosikan program dua anak. Adanya program ini, diharapkan orang akan menjadi lebih sadar akan pentingnya anak-anak dalam keluarga sehingga kejadian kehamilan yang tidak diinginkan juga dapat berkurang karena promosi pencegahan kehamilan yang tidak diinginkan juga hadir dalam program ini.

\section{KESIMPULAN DAN SARAN}

Status kehamilan yang tidak diinginkan masih cukup tinggi. Kehamilan yang tidak diinginkan ini dapat mempengaruhi perilaku ibu untuk tidak melakukan perawatan terhadap kehamilannya. Berdasarkan uraian diatas, dapat disimpulkan bahwa hasil dari model akhir analisis multivariat diperoleh adanya hubungan yang signifikan secara statistik perilaku perawatan kehamilan (kunjungan ANC) terhadap status kehamilan yang tidak diinginkan setelah dikontrol oleh variabel umur saat hamil dan paritas. Peneliti menyarankan harus dilakukan penjaringan kasus ibu hamil dengan status kehamilan yang tidak diinginkan perlu dilakukan dengan bantuan kader agar ibu mau melakukan pemeriksaan kehamilan, memberikan edukasi seputar pentingnya untuk melakukan pemeriksaan terhadap kehamilannya tujuannya untuk mencegah risiko yang dapat terjadi selama kehamilan.

\section{UCAPAN TERIMA KASIH}

Penulis mengucapkan terima kasih kepada Instansi BKKBN Pusat yang telah memberikan akses terhadap penggunaan data set SDKI tahun 2017.

\section{DAFTAR PUSTAKA}

1. WHO. Maternal MortalityIn Reproduction Health and Research. Geneva; 2015.

2. Singh S, Sedgh G, Hussain R. Unintend- 
ed Pregnancy: Worldwide Levels, Trends, and Outcomes. Studies in Family Planning. 2010;41(4):241-250.

3. Kemenkes RI. Riset Kesehatan Dasar (Riskesadas). Jakarta: Kementerian Kesehatan RI; 2013.

4. Central Bureau of Statistic dan Macro International. Indonesia Demographic and Health Survey Data 2012-2017. Central Bureau of Statistic dan Macro International; 2017.

5. Notoatmodjo S. Ilmu Perilaku Kesehatan. Jakarta: Rineka Cipta; 2010.

6. D'Angelo D V, Gilbert BC, Rochat RW, Santelli JS, Herold JM. Differences between Mistimed and Unwanted Pregnancies among Women Who have Live Births. Perspectives on Sex Reproductive Health [Online Journal]. 2004;36(5):192-197.

7. Abdallah IM, Fatouh E, Mone A, Abd M, Sabour E. Determinants and Outcomes of Unintended Pregnancy among Women in Helwan District. Journal of American Science. 2017; 7(11):497-505.

8. Gipson JD, Koenig MA, Hindin MJ. The Effects of Unintended Pregnancy on Infant, Child, and Parental Health: a Review of the Literature. Studies in Family Planning. 2008;39(1):18-38.

9. Adhikari R, Soonthorndhada K, Prasartkul P. Correlates of Unintended Pregnancy among Currently Pregnant Married Women in Nepal. BMC International Health and Human Rights. 2009;9(17):1-10

10. Palamuleni, Martin, Adebowale. Prevalence and Determinantsof Unintended Pregnancy in Malawi. African Population Studies. 2014;28(1):551-563.

11. Notoatmodjo S. Metodologi Penelitian Kesehatan. Jakarta: Rineka Cipta; 2012.

12. Pranata S, Sadewo S. Miscarriage Events, Unplanned Events and Abortion in Indonesia. Health System Research Bulletin. 2012;15(2):180-192.

13. Anggraini K. Niat Kehamilan dan Perilaku Pemeriksaan K1 dan K4 pada Perempuan Usia Reproduksi di Indonesia (Analisis Data SDKI Tahun 2012). [Skripsi]. Depok: Universitas Indonesia; 2014.
14. Hambert.L et.all. The Effect of Pregnancy Intention on Important Maternal Behaviors and Satisfaction with Care in a Socially and Economically at-Risk Population. Maternal and Child Health Journal. 2011;15(7):1055-1066.

15. Tosson SA, Badawy AS, Sara A, Hesa A. Reproductive Health and Neonatal Consequences of Unintended Childbearing among Saudi Women. Journal of Nursing Education and Practice. 2015;5(1):115-120.

16. Kost K, Landry DJ, Darroch JE. The Effects of Pregnancy Planning Status on Birth Outcomes and Infant Care. Family Planning Perspectives. 2015;30(5):223-230.

17. Dye TD, Wojtowycz MA, Aubry RH, Quade J, Kilburn H. Unintended Pregnancy and Breast-Feeding Behavior. American Journal of Public Health. 1997;87(10):1709-1711.

18. Qurniyawati E. Hubungan Usia Ibu Hamil, Jumlah Anak dan Jarak Kehamilan dengan Kehamilan Tidak Diinginkan (KTD) di Bidan Praktek Mandiri Titik Hariningru.[Tesis]. Madiun: Universitas Sebelas Maret; 2015.

19. Pedak M. Petunjuk Lengkap dan Praktis KB Alami. Jogyakarta: Laksana; 2011.

20. Global A. Worker Health Promotion Handbook: Questions and Answers about Reproductive Health. Jakarta: Global Alliance for Workers and Communities-Indonesia; 2013.

21. Goossens J, Branden YVD, Sluys LVd, Delbaere I, Hecke AV, Verhaeghe S, et al. The Prevalence of Unplanned Pregnancy Ending in Birth, Associated Factors, and Health Outcomes. Human Reproduction. 2016; 31(12):2821-2833.

22. Bitto, A., R.H. Gray, J.L. Simpson, J.T. Queenan, R.T. Kambic, A. Perez, P. Mena, M. Bar-bato, C. Li, and V. Jennings. Adverse Outcomes of Planned and Un-planned Pregnancy among Users of Natural Family Planning: A Prospective Study. American Journal of Public Health. 2010;87(3):338-343.

23. Saptarini I, Suparmi. Determinan Kehamilan Tidak Diinginkan di Indonesia (Analisis Data Sekunder Riskesdas 2013). Jurnal Pusat Penelitian dan Pengembangan Upaya Kesehatan. 2016;7(1):15-24. 